\title{
Seed Potentiation under Stressful Storage Condition
}

\author{
Chandan Kumar Pati* \\ Department of Botany, Saldiha College (Affiliated to Bankura University), Saldiha-722 173, Bankura, West \\ Bengal, India
}

*Corresponding Author: Chandan Kumar Pati, Department of Botany, Saldiha College (Affiliated to Bankura University), Saldiha-722 173, Bankura, West Bengal, India

\begin{abstract}
Pretreatment of black gram (Vigna mungo) seeds with the leaf extract of calendula (Calendula arvensis) $25 \mathrm{~g}$ in $500 \mathrm{ml}$ distilled water before accelerated ageing treatment (100\% RH) for different durations $(0,15$ and 30 days) slowed down the rapid loss of seed germination. The plant extract also significantly arrested the reduction of protein and activity of catalase enzyme of seed kernels during forced ageing period. Again, stimulation of the activity of amylase enzyme was alleviated by the seed pretreating agent during ageing. The promising effect of the present plant extract on storage potentiation of the experimental seed species is apparent in this investigation.
\end{abstract}

Keywords: Black gram, calendula, seed potentiation, stressful storage, accelerated ageing.

\section{INTRODUCTION}

The problem of retention of seed vigor particularly in Bankura and Purulia Districts in West Bengal state of India is much more acute because of semiarid climate where high temperature and high relative humidity $(\mathrm{RH})$ prevailing during the major part of a year is very conducive to the growth of microorganisms (Christensen and Kaufmann, 1965; Aziz and. Shair, 1977).Keeping in mind the above problem of seed storing, an attempt has been made in this investigation to prolong the storage life of a black gram species. An experiment of this investigation was carried out under accelerated ageing condition to obtain more or less uniform and expeditious results. In fact, accelerated ageing treatment, as imposed by high temperature and high relative humidity, provide a powerful tool for studying the process of seed deterioration over a very short period (Heydecker, 1972; Pati and Bhattacharjee, 2013).Thus, the prime objective of this work is to probe the efficacy of leaf extract of calendula on enhancement of seed vigour of a black gram species by analysing germination behaviour and metabolic status of seeds.

\section{Materials AND Methods}

After surface sterilization $\left(0.1 \% \mathrm{HgCl}_{2}\right.$ for 90 seconds) the seeds of black gram (Vigna mungo) was presoaked in aqueous solution of leaf extract of calendula (Calendula arvensis) $25 \mathrm{~g}$ in $500 \mathrm{ml}$ distilled water for 2 hours (h) and then dried back to the original dry weight of the seeds. This was repeated twice allowing maximum penetration of the bioactive substances present in the aqueous solution. The pretreated seed lot was taken in cloth bag and thus stored in a desiccator in which $100 \%$ relative humidity $(\mathrm{RH})$ was preimposed within it. This experimental set up was kept at room temperature for allowing the seeds to experience forced ageing treatment for different durations $(0,15$ and 30 days).

To analyse the percentage germination, treated seeds was transferred to separate Petri dishes containing filter paper moistened with distilled water. Germination data was recorded after seed soaking following the International Rules for Seed Testing (ISTA, 1976).Protein as well as activities of catalase and amylase enzymes were analysed from seed kernels of each sample. Quantification of Protein level was estimated as per the method of Lowry et al.,1951.Extraction and estimation of the enzyme catalase was made following the method of Snell and Snell,1971 as modified by Biswas and Choudhuri,1978. Amylase activity was estimated as per the method of Khan and Faust, 1967.

Data were statistically analysed at the treatment and replication levels and least significant difference (LSD) values were calculated at 95\% confidence limits (Panse and Sukhatme, 1967). 


\section{RESULTS AND DISCUSSION}

Data clearly revealed that pretreatment of the black gram seed species with aqueous solution of leaf extract of calendula significantly alleviated the accelerated ageing-induced loss of germination (Table 1), alleviated the loss of protein (Table 1) and catalase enzyme (Table 2) as well as reduces the stimulation of the activity of amylase enzyme (Table 2).

The proposal that a decrease in membrane lesions might play a significant role in deterioration of seeds has been supported by the work on solute leakage accompanying a loss in germinability and viability (Powell and Matthews, 1977; Pati and Bhattacharjee, 2015). Much evidence has been put forward to suggest that membrane status within the germinating embryo is an important factor in deterioration (Pati, 2019). The experimental plant extract-induced substantial amelioration of all these deleterious effects are indicative of seed potentiation under adverse storage environment. The results therefore point out that although deterioration is a common phenomenon in treated and control sample of the seed species, the catabolic processes within the treated seed sample remained somewhat subdued, thereby rendering them tolerant against unfavourable storage environment. In this investigation, the arrestation of rapid loss of the catalase enzyme activity and alleviation of the ageing-induced stimulation of the activity of amylase enzyme are indicative of strengthening the defence mechanism by the bioactive compounds present in the leaf extract of calendula under adverse storage condition.

Table1. Effect of seed pretreatment with aqueous solution of leaf extract of calendula $(25 \mathrm{~g}$ in $500 \mathrm{ml}$ distilled water) on percentage seed germination and protein ( $\mathrm{mg} / \mathrm{g} \mathrm{fr}$. wt.) values of black gram seeds.

\begin{tabular}{|c|c|c|c|c|c|c|c|c|}
\hline \multirow{2}{*}{ Seed sample } & \multirow{2}{*}{ Treatment } & \multicolumn{3}{|c|}{ Percentage seed germination } & \multicolumn{4}{|c|}{ Protein } \\
\cline { 3 - 8 } & & \multicolumn{1}{|c|}{ Days after accelerated ageing } \\
\hline & & $\mathbf{0}$ & $\mathbf{1 5}$ & $\mathbf{3 0}$ & $\mathbf{0}$ & $\mathbf{1 5}$ & $\mathbf{3 0}$ \\
\hline \multirow{3}{*}{ Black gram } & Control & 100 & 77 & 23 & 65.00 & 50.13 & 27.07 \\
\cline { 2 - 8 } & Calendula & 100 & 88 & 46 & 66.30 & 62.00 & 39.20 \\
\cline { 2 - 8 } & LSD $(\mathrm{P}=0.05)$ & NC & 4.15 & 2.10 & NS & 4.04 & 3.19 \\
\hline
\end{tabular}

NC: Not calculated; NS: Not significant.

Table2. Effect of seed pretreatment with aqueous solution of leaf extract of calendula $(25 \mathrm{~g}$ in $500 \mathrm{ml}$ distilled water) on activities of enzyme catalase and amylase ( $\triangle O D x T v / t x v$ of each) of black gram seeds.

\begin{tabular}{|c|c|c|c|c|c|c|c|}
\hline \multirow{3}{*}{ Seed samples } & \multirow{3}{*}{ Treatments } & \multicolumn{3}{|c|}{ Catalase } & \multicolumn{3}{|c|}{ Amylase } \\
\hline & & \multicolumn{6}{|c|}{ Days after accelerated ageing } \\
\hline & & $\mathbf{0}$ & 15 & 30 & $\mathbf{0}$ & 15 & 30 \\
\hline \multirow{3}{*}{ Black gram } & Control & 30.0 & 20.0 & 11.0 & 37.0 & 47.0 & 59.0 \\
\hline & Calendula & 32.0 & 30.0 & 27.4 & 38.0 & 42.7 & 47.5 \\
\hline & $\operatorname{LSD}(\mathrm{P}=0.05)$ & NS & 1.20 & 1.04 & NS & 2.07 & 3.50 \\
\hline
\end{tabular}

NS: Not significant.

\section{CONCLUSION}

It can be concluded from the results of this investigation that aqueous solution of leaf extract of calendula is effective in enhancing storage potential of black gram seeds. Thus, invigouration property of the present seed pretreating agent seems to be apparent from these experimental results.

\section{REFERENCES}

[1] Abdul-Baki, A. A. and Anderson, J. D. 91972). Physiological and biochemical deterioration of seeds, In Seed Biology (ed. T.T. Kozlowski).2(,283-315, Academic Press, New York.

[2] Aziz, N. H. and Shair, A.A.M. (1977). Influence of other fungi on aflatoxin production by Aspergillus flavus in maize kernels, Journal of Food Safety,17( 2), 113-123.

[3] Biswas, A. K. and Choudhuri, M. A. (1978). Differential behaviour of the flag leaf of intact rice plant during ageing, Biochemie und Physiologie der Pflanze,173,220-228.

[4] Christensen, C.M. and Kaufmann, H. H. (1965). Deterioration of stored grain by fungi, Annal Review of Phytopathology, 3, 69-84.

[5] Heydecker,W.(1972).Vigour in Viability of Seeds,(ed. E.H. Roberts),pp. 209-252. Chapmann and Hall Ltd., London.

[6] International Seed Testing Association(1976). International Rules for Seed Testing, Seed Science and Technology,4,51-177. 
[7] Khan, A. A. and Faust, M. A. (1967). Effect of growth retardants on $\alpha$-amylase production in germinating barley seeds,Physiologia Plantarum,20,673-681.

[8] Lowry, O. H. ; Rosebrough, N. J. ; Farr, A. L. and Randall, R. J. (1951). Protein measurement with the Folin-phenol reagent, Journal of Biological Chemistry,193,265-275.

[9] Panse, V. G. and Sukhatme, P. T. (1967). Statistical methods for agricultural workers, 2ed.,150-157, Indian Council of Agricultural Research, New Delhi.

[10] Pati, C. K. and Bhattacharjee, A. (2013). Chemical Manipulation for Storage Potentiation of Crop Seeds, LAP LAMBERT Academic Publishing, Germany.

[11] Pati, C. K. and Bhattacharjee,A.(2015). Retention of seed vigour and enhancement of plant potential of a safflower species by chemical manipulation. Research Journal of Agriculture and Environmental Management.4 (6) ,274-277.

[12] Pati, C. K. (2019). Prolongation of seed viability under storage, World Scientific News, 132,256-263.

[13] Powell, A. A. and Matthews, S.(1977). Deteriorative changes in pea seeds stored in humid or dry conditions, Journal of Experimental Botany. 28,225-234.

[14] Snell, F. D. and Snell, C.T. (1971). Colorimetric methods of analysis.4AAA,7-145. Van Nostrand Reinhold Co., New York.

Citation: Chandan Kumar Pati, "Seed Potentiation under Stressful Storage Condition". International Journal of Advanced Research in Botany (IJARB), vol. 5, no. 4, pp. 15-17, 2019. DOI: http://dx.doi.org/10.20431/2455-4316.0504003.

Copyright: (C) 2019 Authors. This is an open-access article distributed under the terms of the Creative Commons Attribution License, which permits unrestricted use, distribution, and reproduction in any medium, provided the original author and source are credited. 